\title{
Litmus-Body: a Molecularly Targeted Sensor for Cell-Surface pH Measurements
}

\author{
Marc C. Goudge ${ }^{1 \ddagger}$, Joe Chin-Hun Kuo ${ }^{2 \ddagger}$, Ann E. Metzloff ${ }^{2}$, Ling-Ting Huang², Marshall J. Colville ${ }^{3}$, \\ Warren R. Zipfel11,3,4, and Matthew J. Paszek ${ }^{1,2,3,4}$ \\ ${ }^{1}$ Nancy E. and Peter C. Meinig School of Biomedical Engineering, Cornell University, Ithaca, NY 14853, USA \\ 2Robert Frederick Smith School of Chemical and Biomolecular Engineering, Cornell University, Ithaca, NY 14853, USA \\ 3Field of Biophysics, Cornell University, Ithaca, NY 14853, USA \\ ${ }^{4}$ Kavli Institute at Cornell for Nanoscale Science, Ithaca, NY 14853, USA \\ KEYWORDS: $p H$, biosensor, cancer, nanobody, endocytosis, antibody-drug conjugate, glycocalyx
}

\begin{abstract}
Precise $\mathrm{pH}$ measurements in the immediate environment of receptors is essential for elucidating the mechanisms through which local $\mathrm{pH}$ changes associated with diseased phenotypes manifest into aberrant receptor function. However, current $\mathrm{pH}$ sensors lack the molecular specificity required to make these measurements. Herein we present the Litmus-body, our recombinant protein-based $\mathrm{pH}$ sensor, which through fusion to an anti-mouse IgG nanobody is capable of molecular targeting to specific proteins on the cell surface. By normalizing a $\mathrm{pH}$-dependent green fluorescent protein to a long-Stokes shift red fluorophore or fluorescent protein, we readily report $\mathrm{pH}$ independent of sensor concentration using a single 488-nm excitation. Our Litmus-body showed excellent responsiveness in solution, with a greater than 50 -fold change across the physiological regime of $\mathrm{pH}$. The sensor was further validated for use on live cells, shown to be specific to the protein of interest, and was able to successfully recapitulate the numerous $\mathrm{pH}$ changes along the endocytic pathway.
\end{abstract}

Acidification of the extracellular microenvironment is a hallmark of cancer progression ${ }^{1,2}$. In response to an increased anabolic demand associated with uncontrolled proliferation, cancer cells upregulate glycolysis and consequently overproduce protons intracellularly ${ }^{3}$. This excess of protons is then expelled to maintain cellular homeostasis, lowering the $\mathrm{pH}$ of the extracellular space. The consequences of extracellular acidosis are diverse and profound: for example, mutant receptors may become permanently activated in a low $\mathrm{pH}$ environment ${ }^{4}$, and acid-adapted cells show a proclivity towards a more aggressive phenotype ${ }^{5}$. While these effects have been studied in the context of the bulk extracellular $\mathrm{pH}^{6,7}$, work towards elucidating the precise relationship between localized acidity and aberrant cellular function has been limited by the ability to measure $\mathrm{pH}$ at precise locations.

Notably, this localized acidity is further exaggerated at the cancer cell surface ${ }^{8}$. It is suggested that cancer-associated proton secretion creates a concentration gradient of protons that is highest at the cell membrane ${ }^{9,10}$. In addition, negatively charged residues in the glycocalyx, a carbohydrate-enriched cell coat near the pericellular surface, have also been predicted to accumulate protons that lower the local $\mathrm{pH}^{11}$. In concert with cancer-associated acidosis, the content of anionic moieties in the glycocalyx has been shown to increase ${ }^{12}$, which could act synergistically with proton secretion to concentrate protons in the vicinity of cell surface receptors. These factors may lead to heterogeneity in the local pH that receptors experience, significantly impacting their functionality. Although cell surface $\mathrm{pH}$ can be determined by recently developed pH sensitive fluorescent dyes conjugated to $\mathrm{pH}$-low insertion peptides ${ }^{8}$ and cell penetrating peptides ${ }^{13}$, there remains an unmet need in the development of molecularly targeted sensors capable of reporting on the immediate environment of receptors.

Molecular targeting can be achieved by the diverse repertoire of antibody specificity ${ }^{14}$. Monoclonal primary antibodies that target specific cell surface receptors are clinically important for cancer therapies, such as Cetuximab for the cancer types that overexpress epidermal growth factor receptor (EGFR) ${ }^{15}$. Primary antibodies are conventionally detected by a secondary antibody, although its relatively large size $(\sim 150 \mathrm{kDa})$ can be disadvantageous in sample penetration and signal localization ${ }^{16}$. Recently, nanobodies, or single-domain antibodies, have emerged as attractive alternatives for specific binding and localisation to primary antibodies $^{17}$. Specifically, Pleiner et al. have successfully expressed and validated a library for targeting rabbit IgG and all mouse IgG subclasses ${ }^{18}$. Their small size $(\sim 13 \mathrm{kDa})$, ease of labelling and consistent behaviour in recombinant protein fusions make nanobodies well-suited for fluorescence imaging ${ }^{18-20}$.

Fluorescent protein-based biosensors are versatile tools that can be fused to nanobodies for specific targeting ${ }^{21}$. Through extensive protein engineering, derivatives of the green fluorescent protein (GFP) from Aequorea victoria have been selected for $\mathrm{pH}$ dependent fluorescence ${ }^{22-25}$. In particular, pHluorins have been widely used as geneticallyencoded sensors for tracking the $\mathrm{pH}$ of intracellular compartments 22,24 . Notably, the bright $488 \mathrm{~nm}$ excitable super- 
bioRxiv preprint doi: https://doi.org/10.1101/800003; this version posted October $10,2019$. The copyright holder for this preprint (which was not certified by peer review) is the author/funder, who has granted bioRxiv a license to display the preprint in perpetuity. It is made available under aCC-BY-NC-ND 4.0 International license.

ecliptic pHluorin (SEP) variant is a $\mathrm{pH}$ sensor that shows a $\sim 50$-fold signal change between $\mathrm{pH} 5.5$ and 7.5, making it ideal for applications in physiological conditions. One major drawback is the inability to distinguish $\mathrm{pH}$-dependent fluorescence changes from the local variations in its concentration. Without signal normalisation, studies using SEP as a $\mathrm{pH}$ sensor have remained qualitative ${ }^{22}$.

On the other hand, the ratiometric variants exhibit two pH-sensitive UV excitation peaks that can be normalized against each other ${ }^{22}$. This feature is an important advantage over the attributes of SEP as it allows for pH quantification independent of sensor concentration. However, the utility of pHluorin and its fluorescence enhanced variant, pHluorin2, suffers from exposing cells to phototoxic UV light and reporting a limited dynamic range of only $\sim 3$-fold signal change in physiological conditions ${ }^{22,26}$.

Consequently, we aim to take advantage of the superior $\mathrm{pH}$ sensitivity of SEP for $\mathrm{pH}$ quantification by normalising its response against a second fluorophore that displays a large-Stokes shift (LSS). Adopting this strategy could potentially allow the $\mathrm{pH}$ response of SEP to be normalised by a single-wavelength co-excitation at $488 \mathrm{~nm}$, which, in addition to allowing for signal quantification, avoids the photocytotoxicity conferred by UV light excitation. The use of SEP in conjunction with LSS red fluorophores has the added benefit of allowing extra fluorophores to be excited by 594 $\mathrm{nm}$ and $633 \mathrm{~nm}$ confocal laser lines for additional multicolour imaging.

In this work, we describe the Litmus-body, a tandem protein fusion that incorporates an IgG-specific nanobody and an SEP-based sensor that can normalise its $\mathrm{pH}$ response to LSS fluorophores with a single-wavelength excitation. We show here that, as a proof-of-principle, the Litmus-body can be successfully targeted to IgG antibodies and provide $\mathrm{pH}$ measurements when localised to components of interests on the cell surface, as well as following their transit through the endocytic pathway.

\section{EXPERIMENTAL SECTION}

Antibodies and reagents. The following antibodies were used for immunostaining: mouse anti-human Muc1 (CD227) monoclonal antibody (555925; BD Biosciences), goat anti-mouse Alexa Fluor 647 (A-21236; Thermo Fisher Scientific) and mouse anti-human EGFR antibody (225/Cetuximab, MA5-12880; Thermo Fisher Scientific). Doxycycline (sc-204734; Santa Cruz) was used for human cell culture induction, and IPTG (14213-261; IBI Scientific) was used for bacterial culture induction. Kanamycin sulfate (420311; MilliporeSigma) was used for bacterial culture selection. Hoescht 33342 (H1399; Thermo Fisher Scientific) was used for nuclear staining. Normal goat serum (NGS; S1000; Vector Laboratories) was used as a blocking agent. The following buffers were prepared: 2.5X Ni-NTA binding buffer (375 mM NaCl, $125 \mathrm{mM} \mathrm{K}_{2} \mathrm{HPO}_{4}, 25 \mathrm{mM}$ Tris pH 8.5, $25 \mathrm{mM}$ imidazole), Ni-NTA wash buffer (300 mM NaCl, 50 $\mathrm{mM} \mathrm{K}_{2} \mathrm{HPO}_{4}, 20 \mathrm{mM}$ imidazole), Ni-NTA equilibration buffer (300 mM NaCl, $50 \mathrm{mM} \mathrm{K}_{2} \mathrm{HPO}_{4}, 10 \mathrm{mM}$ imidazole), Ni-NTA elution buffer (300 mM NaCl, $50 \mathrm{mM} \mathrm{K2HPO4,} 250 \mathrm{mM}$ imidazole), and maleimide labelling buffer (MLB; $100 \mathrm{mM}$ $\mathrm{K}_{2} \mathrm{HPO}_{4}, 150 \mathrm{mM} \mathrm{NaCl}, 1 \mathrm{mM}$ EDTA, $250 \mathrm{mM}$ sucrose). Unless otherwise stated, all chemicals were purchased from
MilliporeSigma, cell culture reagents were purchased from Thermo Fisher Scientific and enzymes for molecular cloning were purchased from New England Biolabs (NEB).

Construct generation. A dsDNA oligo encoding a cysteine-free SEP (cfSEP) engineered with an additional C-terminal surface cysteine (IDT), using NEB HiFi Assembly, was inserted into a BamHI-HF and NcoI-HF linearized pTP1112 vector (generously provided by Dirk Görlich: Addgene plasmid \#104158) ${ }^{18}$. pTP1112 encodes an N-terminal His ${ }_{14}$ $b d$ NEDD8 tagged anti-mouse IgG1 Fc specific TP1107 nanobody with an ectopic C-terminal cysteine. This terminal cysteine was removed and replaced with a Gly-Gly-Gly-Gly-Ser flexible linker, to ensure that downstream cysteine-maleimide labelling only occurred at the cfSEP C-terminal cysteine and to improve folding of the fusion protein. These steps generated a His 14 - $b d$ NEDD8-TP1107-cfSEP construct.

mCyRFP1 was extracted from a mMaroon-mCyRFP1pET11(a) construct (unpublished work) using the Q5 Hot Start High-Fidelity Master Mix (NEB) with 5'ATGAACTGTACAAAGGAGGAGGCGGTAGCATGGTTAGTAAA GGCGAAGAAC-3' (forward) and 5' CCAAGCTCAGCTAAAGCTTATTTATACAGTTCATCCATGC-3' (reverse). The His14-bdNEDD8-TP1107-cfSEP construct was linearized with Gibson Assembly compatible ends (forward: 5'-TAAGCTTTAGCTGAGCTTGGAC-3', and reverse 5'CATGCTACCGCCTCCTCCTTTGTACAGTTCATCCATG-3'

(note: the engineered cfSEP C-terminal cysteine was removed and replaced with a Gly-Gly-Gly-Gly-Ser flexible linker). Afterwards, the linear fragments were combined via NEB HiFi Assembly to form a His $14-b d$ NEDD8-TP1107cfSEP-mCyRFP1 construct.

Single fluorescent proteins were generated via Q5 site-directed deletion of the His14- $b d N E D D 8-T P 1107-c f S E P-$ mCyRFP1 construct. $b d$ NEDD8, TP1107 nanobody, and the unneeded fluorescent protein were deleted using the following primer pairs: 5' ATGGTTAGTAAAGGCGAAGAACTGATT-3' (forward) with 5'-TGATCCGCCGGTATGGTGATGACT-3' (reverse) to isolate a His14-mCyRFP construct, and 5'ATGGTGAGTAAAGGAGAAGAACTTTTCACTGG-3' (forward) with 5'-TGATCCGCCGGTATGGTGATGACT-3' (reverse) to isolate a His14-cfSEP construct.

His 14 -SEP was made by a two-fold site-directed mutagenesis of the His14-cfSEP construct in order to generate linear fragments compatible for NEB HiFi Assembly. The S48C mutation was generated using $5^{\prime}$ CTTACCCTTAAATTTATTTGCACTACTGGAAAACTACC-3' (forward) and 5' TGATCTGGGTATCTTGAAAAGCATTGAACACCATAAGT-3', and the M70C mutation was generated with 5'ACTTATGGTGTTCAATGCTTTTCAAGATACCCAGATCA-3' (forward) and 5' GGTAGTTTTCCAGTAGTGCAAATAAATTTAAGGGTAAG-3'

(reverse). The two linear strands were subsequently joined.

Cell lines and cultures. All cells were maintained with $100 \mathrm{U} / \mathrm{mL}$ Penicillin/Streptomycin at $37{ }^{\circ} \mathrm{C}, 90 \%$ relative humidity, and 5\% CO2. A previously described MCF10A cell line that stably expressed a doxycycline-inducible rtTA NeoR Mucin-1 (Muc1) deficient of cytoplasmic tail (dCT) was cultured in DMEM/F12 media supplemented with 5\% horse serum, 20 ng/mL EGF (Peprotech), 10 mg/mL insulin, 
bioRxiv preprint doi: https://doi.org/10.1101/800003; this version posted October 10, 2019. The copyright holder for this preprint (which was not certified by peer review) is the author/funder, who has granted bioRxiv a license to display the preprint in perpetuity. It is made available under aCC-BY-NC-ND 4.0 International license.

$500 \mathrm{ng} / \mathrm{mL}$ hydrocortisone, and $100 \mathrm{ng} / \mathrm{mL}$ cholera toxin ${ }^{27}$. A431 cells (ATCC) were cultured in DMEM supplemented with $10 \%$ FBS, 1 mM pyruvate, and 1X Glutamax.

Recombinant protein production and purification. All recombinant proteins were expressed in chemically competent NiCo21 (DE3) E. coli (NEB). $5 \mathrm{~mL}$ precultures (LB containing $50 \mu \mathrm{g} / \mathrm{ml}$ kanamycin) were grown overnight at 37 ${ }^{\circ} \mathrm{C}, 220 \mathrm{rpm}$ and then diluted with fresh medium to $0.2-1 \mathrm{~L}$, in baffled flasks at no more than a 1:10 media:container volume ratio, and allowed growth to reach OD600 of just below 0.6 . The cultures were induced by $0.5 \mathrm{mM}$ IPTG overnight at $24^{\circ} \mathrm{C}$, harvested, resuspended in B-PER (Thermo Fisher Scientific) and vortexed for cell lysis. The lysates were cleared by centrifugation at $10,000 \mathrm{~g}$ for $20 \mathrm{~min}$ at $4{ }^{\circ} \mathrm{C}$.

His 14 -tagged recombinant proteins were purified using immobilized metal affinity chromatography. Supernatant diluted into $1 \mathrm{X}$ Ni-NTA binding buffer was bound to equilibrated Ni-NTA resin for $20 \mathrm{~min}$ at $4{ }^{\circ} \mathrm{C}$, with end-over-end mixing. The resin was added to a spin column, washed thoroughly and incubated with the Ni-NTA elution buffer for 20 min at $4{ }^{\circ} \mathrm{C}$, with end-over-end mixing. Recombinant proteins were then eluted and buffer exchanged (fluorescent proteins to $\mathrm{pH} 7.4 \mathrm{PBS}$, and $b d \mathrm{NEDP} 1$ to $50 \mathrm{mM}$ Tris- $\mathrm{HCl}$, $300 \mathrm{mM} \mathrm{NaCl}, 250 \mathrm{mM}$ sucrose, $10 \mathrm{mM}$ DTT, pH 7.5) using Zeba 7k MWCO desalting columns or by overnight dialysis with 10k MWCO Snakeskin dialysis tubing. Eluted proteins were then sterile filtered and snap-frozen for long-term storage at $-80{ }^{\circ} \mathrm{C}$. Nanobody-containing constructs were mixed with $0.1 \% \mathrm{w} / \mathrm{v}$ sodium azide prior to snap-freezing.

NEDD8-removal. $b d$ NEDP1 protease expressed from the pDG02583 construct (a gift from Dirk Görlich; Addgene plasmid \# 104129) was used to remove $b d N^{N E D D 8}{ }^{28}$. Ni-NTA purified His $14-b d$ NEDD8-tagged proteins were incubated with $>500 \mathrm{nM}$ of the protease for $2 \mathrm{~h}$ on ice. The proteaseprotein mixture was incubated with equilibrated Ni-NTA resin for $20 \mathrm{~min}$ and spun at $700 \mathrm{~g}$ to elute the cleaved protein while leaving the uncleaved protein and the protease bound to the column. The cleaved protein was then buffer exchanged using a Zeba 7k MWCO desalting column to $\mathrm{pH}$ 7.4 PBS, prior to filtration and snap-freezing.

ATT0490LS-maleimide labelling. Cysteine-maleimide labelling was performed as previously described and all steps were kept on ice to protect internal cysteines from the labelling reaction ${ }^{20}$. Briefly, the engineered cfSEP C-terminal cysteine was reduced by $15 \mathrm{mM}$ TCEP for $10 \mathrm{mins}$. TCEP was removed by buffer exchange to degassed MLB using a Zeba 7k MWCO desalting column (Thermo Fisher Scientific). ATTO490LS-maleimide (ATTO-TEC Gmbh) was added to the reduced TP1107-cfSEP at a 6:5 molar ratio and the reaction-mixture was brought to $\mathrm{pH} 7.5$ with $\mathrm{K}_{2} \mathrm{HPO}_{4}$. The mixture was stirred on ice under nitrogen for $1.5 \mathrm{~h}$. Excess ATT0490LS was removed through buffer exchange to MLB.

SYPRO Ruby protein gel staining. Proteins were diluted with 4x NuPAGE LDS Sample Buffer (Thermo Fisher Scientific) and heated at $70^{\circ} \mathrm{C}$ for $10 \mathrm{~min}$. Proteins were subsequently separated by SDS-PAGE on a 4-12\% NuPAGE BisTris pre-cast gradient gel (Thermo Fisher Scientific) at 200V for $35 \mathrm{~min}$. Gels were fixed, stained with SYPRO Ruby Protein Gel Stain (Thermo Fisher Scientific), and washed according to manufacturer's specification. Washed gels were imaged on a ChemiDoc MP Imaging System (Bio-rad).
Photophysical properties. Quantum yield was determined at $490 \mathrm{~nm}$ in PBS, $\mathrm{pH}$ 7.4, by acquiring integrated fluorescence $(500 \mathrm{~nm}-800 \mathrm{~nm})$ in conjunction with absorbance values in a dilution series from $A_{490} \sim 0.1$, to minimize inner filtering effect, using fluorescein as a standard (Quantum yield $=0.925$ at $0.1 \mathrm{M} \mathrm{NaOH})^{29}$. Molar extinction coefficient was determined by measuring mature chromophore concentration under $\mathrm{NaOH}$ denaturing conditions. Absorbance at $450 \mathrm{~nm}$ was measured immediately after mixing proteins with equal volume of $2 \mathrm{M} \mathrm{NaOH}^{30,31}$. This assumed alkali-denatured chromophore exhibited extinction coefficient $44,000 \mathrm{M}^{-1} \mathrm{~cm}^{-1}$ at $450 \mathrm{~nm}$ absorbance. Total protein concentration was determined at $280 \mathrm{~nm}$ absorbance. All absorbance was measured on a Cary 300 UV-VIS spectrometer (Agilent Technologies Inc.) and fluorescence spectra were recorded by a QM4 fluorimeter (Horiba Instruments/Photon Technology International). Brightness was calculated as the product between quantum yield and extinction coefficient.

Fluorescence lifetimes were measured by time-correlated single photon counting (TCSPC). Sample solutions were excited by a $445 \mathrm{~nm}$ picosecond diode laser (BDL-445SMC, Becker \& Hickl GmbH) pulsed at a $20 \mathrm{MHz}$ repetition rate. Fluorescence decay curves were collected from samples in $1 \mathrm{~cm}$ pathlength quartz cuvettes at 90 degrees to the $445 \mathrm{~nm}$ excitation using a R3809U-50 microchannel plate photomultiplier tube with a 25 ps transit time spread (Hamamatsu, Bridgewater, NJ). Excitation intensity was attenuated using a Glan-Thompson polarizer to keep the phospholuminescence detection rate less than $0.2 \%$ of the repetition rate to avoid photon pile-up. Data was acquired using a TCSPC module (SPC-830, Becker \& Hickl GmbH) and fit to a bi-exponential decay using the SPCImage software (Becker \& Hickl GmbH).

Solution pH response. Universal buffer solutions were prepared according to the Carmody buffer series ${ }^{32}$. This involved mixing a master acid buffer $(0.2 \mathrm{M}$ Boric Acid, 0.05 $\mathrm{M}$ Citric Acid) and a master base buffer (0.1 $\left.\mathrm{M} \mathrm{NaHPO}_{4}\right)$ at previously determined ratios to achieve approximate $\mathrm{pH}$ of interest. Fluorescent constructs were diluted to $100 \mathrm{nM}$ in these buffers, and the $\mathrm{pH}$ of the buffer-protein solution was recorded using an Orion ${ }^{\text {TM }}$ PerpHecT ${ }^{\text {TM }}$ ROSS $^{\text {TM }}$ Combination pH Micro Electrode (Thermo Fisher Scientific). The bufferprotein solutions had their emission spectra measured using a Tecan $1000 \mathrm{M}$ Infinite plate reader at $490 \mathrm{~nm}$ excitation. Three sets of triplicates were recorded for each bufferprotein solution. pKa and Hill coefficient were determined by least square non-linear fitting the normalized data to the five-parameter logistic Richards equation on GraphPad Prism (California USA). Fold change was calculated as the intensity ${ }_{\mathrm{pH} 7.5} /$ intensity $_{\mathrm{pH} 5.5}$, where the values at specific $\mathrm{pH}$ were determined through linear interpolation.

Cell binding assay. Doxycycline-induced MCF10A Muc1dCT cells were fixed with 4\% paraformaldehyde for 10 min at room temperature and blocked in PBS containing 5\% NGS for $1 \mathrm{~h}$ at room temperature. All subsequent dilutions were performed in PBS containing 5\% NGS. As a positive control, cells were incubated with the primary anti-Muc1 antibody at $1: 1,000$ dilution overnight at $4{ }^{\circ} \mathrm{C}$ and detected using the secondary Alexa Fluor 647-labelled goat antimouse IgG at 1:1,000 dilution for $1 \mathrm{~h}$ at room temperature. 
bioRxiv preprint doi: https://doi.org/10.1101/800003; this version posted October 10, 2019. The copyright holder for this preprint (which was not certified by peer review) is the author/funder, who has granted bioRxiv a license to display the preprint in perpetuity. It is made available under aCC-BY-NC-ND 4.0 International license.

To test Litmus-body as a secondary reagent, cells were incubated with the primary anti-Muc1 antibody at a 1:1,000 dilution overnight at $4{ }^{\circ} \mathrm{C}$ and then incubated with $30 \mathrm{nM}$ of the Litmus-body for $1 \mathrm{~h}$ at room temperature. For one-step immunostaining, Litmus-body was pre-incubated with the anti-Muc1 antibody at equimolar ratio overnight at $4{ }^{\circ} \mathrm{C} .30$ $\mathrm{nM}$ of the pre-incubated IgG-Litmus-body complex was then applied to cells for $1 \mathrm{~h}$ at room temperature. For negative controls, cells were labelled with $30 \mathrm{nM}$ Litmus-body for 1 $\mathrm{h}$ at room temperature in the absence of a primary IgG antibody. All samples were labelled with Hoechst at $1 \mu \mathrm{g} / \mathrm{mL}$ for 15 min. Cells were then imaged on a Zeiss 800 LSM microscope using a 20X air objective (NA 0.8).

Muc1 live cell imaging. Mouse anti-human Muc1 monoclonal antibody and Litmus-body were mixed at equimolar ratio, $4{ }^{\circ} \mathrm{C}$, overnight, to form an IgG-Litmus-body complex. Doxycycline-induced MCF10A Muc1dCT cells were incubated at $37{ }^{\circ} \mathrm{C}$ for 30 min with PBS containing 5\% NGS and $0.1 \%$ sodium azide to inhibit endocytosis. Cells were then incubated further with $33 \mathrm{nM}$ of the IgG-Litmus-body complex at $37^{\circ} \mathrm{C}$ for $30 \mathrm{~min}$, washed and imaged in PBS containing $5 \%$ NGS and $0.1 \%$ sodium azide with pH adjusted to 6 , 7.03 and 7.95 by an Orion ${ }^{\mathrm{TM}}$ PerpHecT ${ }^{\mathrm{TM}}$ ROSS $^{\mathrm{TM}}$ Combination pH Micro Electrode (Thermo Fisher Scientific). Spectral imaging was performed using lambda mode, at $488 \mathrm{~nm}$ excitation and $9 \mathrm{~nm}$ spectral resolution, on a Zeiss LSM880 inverted confocal microscope with a $40 \mathrm{X}$ water objective (NA 1.1).

Quantification of lambda mode images. Thresholding was applied to the 22 channel, 16-bit Lambda-stacked images based on the pixel intensity values of the cfSEP and mCyRFP1 emission channels (cfSEP channel wavelength: $513 \mathrm{~nm}$, mCyRFP1 channel wavelength: $593 \mathrm{~nm}$ ). Pixels below the threshold (750 AU) in either of the two channels were ignored for the calculation. Mean of the nonthresholded pixels was subsequently used for calculating the average spectra of the selected image subsets, as well as for normalizing the displayed stacks.

Endocytosis studies. Mouse anti-human EGFR monoclonal antibody (225/Cetuximab) and Litmus-body were mixed at equimolar ratio, $4{ }^{\circ} \mathrm{C}$, overnight, to form an IgG-Litmus-body complex. To generate a calibration curve, the IgGLitmus-body complex was diluted to a final concentration of $200 \mathrm{nM}$ in PBS containing 5\% NGS and adjusted to final $\mathrm{pH}$ values of $4,5.04,5.49,6.09,6.56,7.01,7.49,7.91$ using an Orion $^{\text {TM }}$ PerpHecT $^{\text {TM }}$ ROSS $^{\text {TM }}$ Combination pH Micro Electrode (Thermo Fisher Scientific). Least square non-linear fitting was performed using the four-parameter logisticmodel on GraphPad Prism (California USA). IgG-Litmusbody fluorescence in each $\mathrm{pH}$ buffer was then acquired on a Zeiss LSM800 inverted confocal microscope using a $63 \mathrm{X}$ water objective (NA 1.2). The microscope was configured to simultaneously scan for cfSEP and mCyRFP1 signal with $488 \mathrm{~nm}$ excitation. To minimize cross-talk, the emission bands were set to collect between 500 - $535 \mathrm{~nm}$ for cfSEP and $575-700 \mathrm{~nm}$ for mCyRFP1.

For intracellular trafficking experiments, A431 plated overnight at 10,000 cells $/ \mathrm{cm}^{2}$ were chilled on ice for $1 \mathrm{~h}$ to slow down endocytosis, washed and incubated with $67 \mathrm{nM}$ of the IgG-Litmus-body complex in PBS containing 5\% NGS at $37{ }^{\circ} \mathrm{C}$ for $30 \mathrm{~min}$. Cells were washed and allowed to undergo endocytosis for $1 \mathrm{~h}$ at $37^{\circ} \mathrm{C}$. They were further washed and placed in a pH 7.5 PBS buffer containing 5\% NGS for imaging. Cells were then placed in a pH 5.2 PBS buffer containing 5\% NGS and imaged. Cell imaging was done on a Zeiss LSM800 inverted confocal microscope using a $63 \mathrm{X}$ water objective (NA 1.2) and Litmus-body imaging used the same configuration for generating the calibration curve above.

\section{RESULTS AND DISCUSSION}

Litmus-body and expression. We set out to create Litmus-body, a nanobody-sensor fusion, that can be specifically targeted to mouse IgG antibodies to report on the local $\mathrm{pH}$ of cell surface components. Sensor fusion proteins were produced in E. coli for ease of culture and scaling. We took advantage of a highly soluble protease-cleavable tag previously reported by Frey and Görlich (bdNEDD8) to optimise expression of the nanobody component in our sensor ${ }^{28}$. Removable by its associated protease $b d$ NEDP1, the $b d$ NEDD8 tag has been shown to improve the cytoplasmic yield of nanobodies in E. coli (Supplemental Figure 1). To generate an IgG specific Litmus-body, we fused fluorescent sensor proteins to $b d$ NEDD8-TP1107, an anti-mouse IgG Fc fragment nanobody, that allowed the $\mathrm{pH}$ sensor to be applied in a manner analogous to secondary antibodies upon cleavage of NEDD8 (Figure 1A).

Design and validation of a cysteine-free SEP engineered for maleimide chemistry. To explore the potential use of a synthetic dye for $\mathrm{pH}$ signal normalisation, we created a cysteine-free SEP (cfSEP) engineered with an ectopic C-terminal cysteine for site-specific maleimide-dye labelling (Figure 1B). Unlike conventional non-selective modifications, such as via $\mathrm{N}$-hydroxysuccinimide ester, maleimide reaction on $\mathrm{C}$-terminal cysteines has been demonstrated to be an effective protein labelling strategy that produces homogenous protein-dye-ratio conjugates, reduces batch-tobatch variation and does not alter binding properties of the modified protein ${ }^{20,33}$.

We introduced C48S/C70M mutations to remove the native cysteines in SEP and generated cfSEP. This was to avoid off-target cysteine-maleimide reactions and to ensure that only the engineered C-terminal cysteine would be available for dye-conjugation. C48S/C70M mutations have previously been validated in GFP derivatives and shown to maintain fluorescence performance in EGFP, a pH sensitive protein with similar characteristics to SEP ${ }^{34}$. cfSEP with the engineered $\mathrm{C}$-terminal cysteine was tested for its $\mathrm{pH}$ response. It retained similar idea $\mathrm{pKa}$ and responsiveness to SEP in the physiological range, while also displaying consistent photophysical properties to SEP (Table 1, Supplemental Table 1, Supplemental Figure 2A). These results pointed to the suitability of cfSEP as a substitute for SEP.

Expression and $\mathrm{pH}$ response of TP1107-cfSEPATT0490LS. ATT0490LS-maleimide was conjugated to TP1107-cfSEP on the engineered C-terminal cysteine to generate a TP1107-cfSEP-ATT0490LS construct (Figure 1B). ATT0490LS is a long-stoke shift synthetic dye with peak excitation at $496 \mathrm{~nm}$. These properties make ATT0490LS an attractive normalisation partner for cfSEP as both fluorophores can be simultaneously excited and individually resolved (Figure 1C). We recorded the 
bioRxiv preprint doi: https://doi.org/10.1101/800003; this version posted October 10, 2019. The copyright holder for this preprint (which was not certified by peer review) is the author/funder, who has granted bioRxiv a license to display the preprint in perpetuity. It is made available under aCC-BY-NC-ND 4.0 International license.

fluorescence response to solution $\mathrm{pH}$ of the TP1107-cfSEPATT0490 LS construct (Figure 1D). The response of the conjugate at $510 \mathrm{~nm}$ emission (Supplemental Figure 2C) showed a similar pKa and responsiveness to the unconjugated cfSEP (Supplemental Table 1), indicating that fusion and labelling of cfSEP did not negatively impact functionality. pH response of TP1107-cfSEP-ATTO490LS was determined by normalising cfSEP signal against ATTO490LS (Figure 1D). The construct readily detected $\mathrm{pH}$ changes in the physiological regime, exhibiting $>50$-fold signal enhancement from pH 5.5 to 7.5. Interestingly, we noted that the 630 $\mathrm{nm}$ emission in the construct increased at a rate greater than both the cfSEP and ATTO490LS individually (Supplemental Figure 2B, 2C), potentially indicating the occurrence of fluorescence resonance energy transfer (FRET) between cfSEP and ATTO490LS. We subsequently found that the fluorescence lifetime of the combined construct ( $\sim 1.5 \mathrm{~ns}$ ) was lower than that of cfSEP ( $\sim 2 \mathrm{~ns})$, further pointing to the occurrence of FRET.

Expression and pH response of TP1107-cfSEPmCyRFP1. To avoid the complication of FRET in our construct, we looked to monomeric cyan-excitable red fluorescent protein (mCyRFP1) instead as a normalisation partner for cfSEP. mCyRFP1 is a long-stokes shift TagRFP derivative with broad-excitation around $500 \mathrm{~nm}^{30}$. Like ATTO490LS, mCyRFP1 can be co-excited with cfSEP while displaying an easily separable emission. The C-terminal cysteine on cfSEP was removed and replace by a flexible GGGGS peptide linker to fuse to mCyRFP1. We recorded the fluorescence response to solution $\mathrm{pH}$ of the construct. The $510 \mathrm{~nm}$ emission of the construct showed a pKa and responsiveness similar to the unconjugated cfSEP (Supplemental Figure 2D, Supplemental Table 1), suggesting that fusion to a red fluorophore did not impact cfSEP performance. mCyRFP1 showed a distinctive and consistent $\mathrm{pH}$ response, which was retained in the $590 \mathrm{~nm}$ emission of the construct (Figure 1D, Supplemental Figure 2D).

The $\mathrm{pH}$ response of TP1107-cfSEP-mCyRFP1 was determined by normalising cfSEP signal against mCyRFP1's contribution (Figure 1D). TP1107-cfSEP-mCyRFP1 performed similarly to TP1107-cfSEP-ATT0490LS, also exhibiting $>50$-fold signal increase from $\mathrm{pH} 5.5$ to 7.5. Moreover, the mCyRFP1 fused construct benefited from the additional $\mathrm{pH}$ responsiveness of mCyRFP1 above $\mathrm{pH}$ 8. This supplemented the overall responsiveness of the sensor upon the saturation of the cfSEP signal and extended the range of $\mathrm{pH}$ sensitivity in more basic environments (Figure 1D). We thus moved forward with the TP1107-cfSEP-mCyRFP1 construct for cellular testing and hereinafter referred to it as the Litmus-body.

Molecular targeting and response to environmental pH on live cells. Litmus-body was targeted to specific cancer cell surface components by its ability to piggyback on IgG antibodies. Mucin-1 (Muc1) was selected as an epitope of interest given its key role in forming the cancer cell glycocalyx $^{27,35,36}$. Fixed Muc1-overexpressing cells stained with a primary anti-Muc1 IgG antibody could be similarly detected either by a secondary antibody or by using the IgGspecific Litmus-body as a secondary reagent (Figure 2A). We also allowed the Litmus-body to react to the primary anti-Muc1 IgG antibody at an equimolar ratio before cell application to optimize incubation time for live cell applications. The IgG-Litmus-body complex exhibited a similarly high specific binding to the surface of Muc1-overexpressing cells (Figure 2B). These results verified that the specificity of TP1107 binding to IgG antibodies was unaffected in the sensor construct and that Litmus-body could be used as a simple, one-step targeting reagent by pre-complexing with an IgG antibody.

The IgG-Litmus-body complex was targeted to the surface of live Muc1-overexpressing cells and tested for its response to environmental $\mathrm{pH}$. We treated these cells with sodium azide to inhibit endocytosis and minimize the internalization of the $\mathrm{pH}$ sensor. cfSEP and mCyRFP1 were simultaneously excited with a $488 \mathrm{~nm}$ laser and spectrally imaged. Emission peaks were observed in normalized spectra around the expected $510 \mathrm{~nm}$ and $583 \mathrm{~nm}$ for cfSEP and mCyRFP1, respectively. Increasing bulk solution $\mathrm{pH}$ from 6 to 8 brought about a concurrent signal increase of cfSEP relative to mCyRFP1 on the cell surface (Figure 2C, 2D, 2E). These results suggested that the IgG specific Litmus-body could be readily targeted to the cell surface and may act as a suitable agent to report local $\mathrm{pH}$ perturbations on the surface of live cells.

pH imaging of cell surface receptor following endocytosis. We further explored the cellular applications of the Litmus-body by following its intracellular trafficking after binding to epidermal growth factor receptor (EGFR), an overexpressed drug target on multiple cancer types ${ }^{37}$. The endocytic pathway provides an ideal environment for validating our Litmus-body, given its diverse range of $\mathrm{pH}$ values that are well-characterized in cellular compartments along the pathway ${ }^{38}$. Confocal imaging experiments were configured to simultaneously excite and collect the emission of both cfSEP and mCyRFP1 to avoid excessive photobleaching. As above, for simple one-step targeting, Litmus-body was first reacted to a monoclonal anti-EGFR IgG antibody. We selected Cetuximab/C225 anti-EGFR antibody for this purpose due to its clinical importance for treating multiple cancer types including skin, colorectal, head and neck ${ }^{39,40}$. Cetuximab blocks ligand binding to EGFR and induces receptor mediated endocytosis ${ }^{41}$. After reacting the Litmusbody to Cetuximab, a calibration curve was obtained on the confocal by curve fitting of cfSEP/mCyRFP1 fluorescence ratio in solution (Figure $3 \mathrm{~A}$ ).

The Cetuximab-Litmus-body complex was applied to A431 epidermoid cancer cells, which overexpressed EGFR by gene amplification ${ }^{42}$, and allowed to be internalized by receptor-mediated endocytosis at $\mathrm{pH} 7.5$ (Figure 3B). We then switched the bulk solution to $\mathrm{pH} \sim 5$ to quench cfSEP signal on the cell surface. cfSEP and mCyRFP1 signals were observed in the composite images (Left panels, Figure 3C) and were processed to represent their fluorescence ratio (Figure 3D). These ratios were converted to $\mathrm{pH}$ values based on the calibration curve (Figure 3A \& 3D). Interestingly when the bulk solution was adjusted to $\mathrm{pH} 7.5$, regions on the membrane were observed at a slightly lower $\mathrm{pH}$ of $\sim 7.2$ (Top panel, Figure 3D). This is consistent with previous reports suggesting that cancer cell surfaces have a lower $\mathrm{pH}$ than the bulk extracellular environment ${ }^{8}$.

In contrast, Litmus-body sequestered inside endocytic vesicles reported $\mathrm{pH}$ ranges from $\sim 5$ to 6.5 (Figure 3D). 
bioRxiv preprint doi: https://doi.org/10.1101/800003; this version posted October 10, 2019. The copyright holder for this preprint (which was not certified by peer review) is the author/funder, who has granted bioRxiv a license to display the preprint in perpetuity. It is made available under aCC-BY-NC-ND 4.0 International license.

Note that these Litmus-body-loaded intracellular vesicles were similar in size to endosomes and reported the expected $\mathrm{pH}$ values for these compartments (Figure 3B). At a bulk solution of $\mathrm{pH}$ 5.2, the cell surface $\mathrm{pH}$ reported by Litmus-body closely matched the bulk solution pH (Bottom panel, Figure 3D) though its membrane signal became less defined, possibly due to its dissociation from EGFR at low $\mathrm{pH}^{43}$. In contrast, the juxtaposed intracellular compartment reported $\mathrm{pH} \sim 6.5$ against the low cell surface $\mathrm{pH}$. Altogether, these results suggested that our Litmus-body could be a useful tool for reporting the microenvironmental $\mathrm{pH}$ that its molecular targets may experience.

\section{CONCLUSION}

Cell surface acidification is a hallmark of aggressive diseases such as cancer ${ }^{1,2}$. Here, we presented the Litmusbody, an IgG-specific pH sensor in which we fused together an anti-mouse IgG TP1107 nanobody, a pH responsive cysteine-free super-ecliptic pHluorin (cfSEP) and a large-stoke shift monomeric cyan-excitable red fluorescent protein (mCyRFP1), and demonstrated its ability to quantitatively monitor the local $\mathrm{pH}$ surrounding cell surface targets. Coexcitation and separable emission of cfSEP and mCyRFP1 made it possible to normalize the $\mathrm{pH}$ response of the Litmus-body by a single-wavelength excitation. By engineering cfSEP for maleimide labelling, we also described a synthetic dye-conjugate variant with a large-stoke shift ATT0490LS that replaced mCyRFP1 for signal normalization. The dye-conjugate would benefit from the reduced size of a synthetic dye (ATTO490LS; $<1 \mathrm{kDa}$ ) compared to a fluorescent protein (mCyRFP1; $26.4 \mathrm{kDa}$ ), though we observed considerable fluorescence resonance energy transfer (FRET) between cfSEP and ATTO490LS. Further improvements on the use of a $488 \mathrm{~nm}$-excitable large-stoke shift dye without spectral overlap with cfSEP would minimise the complications of FRET. This highlights the utility of the modular design of the Litmus-body. As new fluorophores are developed, components may be swapped out for the current state of the art.

The modular design of the Litmus-body would allow the nanobody domain to be swapped for other targeting variants. While we focused our proof-of-principle studies on monoclonal anti-mouse IgG antibodies as their derivatives play important roles in therapeutic antibodies in the clinic $^{44,45}$, we envisage that the anti-mouse IgG nanobody domain can be easily replaced by anti-IgG nanobodies that are currently available from other species including rabbit $^{18}$. Furthermore, while unexplored in our work, a diverse palette of nanobodies have been developed for commonly expressed molecular targets including EGFR ${ }^{46}$. Litmus-body variants that can be directly localized to targets of interest would remove the need for a primary antibody, and further benefit from the small size of the Litmus-body to maximize cell and tissue sample penetration and perfusion.

Preformed IgG-Litmus-body complexes derived from reacting IgG antibodies to the Litmus-body provided a simple, time-effective one-step targeting strategy for live cell applications. This approach benefited from the monomeric and monovalent nature of anti-IgG nanobodies, as they do not cross-link primary antibodies to form large multimeric complexes that impede IgG binding ${ }^{18}$. Using this strategy, we targeted the Litmus-body to two oncogenic cell surface proteins that are overexpressed in multiple cancer types: Muc1 and EGFR ${ }^{37,47}$, and demonstrated that the Litmusbody responded well to $\mathrm{pH}$ changes surrounding these proteins. Importantly, the Litmus-body reported a decreased pH surrounding EGFR on the cancer cell surface compared to the bulk solution. This observation is consistent with recent reports in the literature that suggest the $\mathrm{pH}$ on cancer cell surfaces is lower than the bulk microenvironment ${ }^{8}$. The ability to target cell surface proteins is a major advantage of the Litmus-body over current strategies in the literature that lack molecular specificity, such as using low $\mathrm{pH}$ insertion peptides ${ }^{8}$, and paves the way to elucidating the mechanisms that give rise to their aberrant function in the cancerous phenotype. The ability of the Litmus-body to piggyback on the vast diversity and high specificity of IgG antibodies may prove to be a powerful approach that opens up an almost infinite number of molecular targets.

Antibody trafficking into acidic intracellular compartments may be important for payload release in the design of antibody-drug conjugates (ADCs) used in cancer therapies $^{48}$. In our proof-of-principle studies, Litmus-body reported on the $\mathrm{pH}$ surrounding the internalized Cetuximab, an EGFR specific antibody used in cancer treatment that is undergoing active research for ADC based therapies ${ }^{49}$. This intracellular tracking was enabled by the single-wavelength co-excitable and dual-emission nature of the Litmus-body that permitted the accurate co-localisation of cfSEP and mCyRFP1. Simultaneous excitation of fluorophores with a single-wavelength light can minimize the effect of sample movement, uneven sensor distribution and sample thickness variations ${ }^{50}$. It also reduced image acquisition time, phototoxicity and unnecessary photobleaching. These factors were particularly important when the Litmus-body complexes were sequestered inside fast-moving endosomal vesicles in living cells ${ }^{51}$. These properties may be valuable in tracking ADCs transiting through intracellular compartments. ADCs typically exhibit specificity for molecules on the cancer cell surface and deliver cytotoxic payload once internalized and reach acidic lysosomes. For example, drug conjugation strategies that take advantages of acid-labile linkers can release payload in low $\mathrm{pH}$ compartments. Traditionally, ADCs are designed to have high affinity for their target at acidic pH. More recently, "acid-switched" ADCs that instead shows high affinity for their target at neutral $\mathrm{pH}$ can have improved lysosomal trafficking with enhanced payload delivery and cytotoxicity ${ }^{52}$. In either case, Litmusbody may potentially be useful in monitoring the $\mathrm{pH}$-sensitive payload delivery of ADCs, as well as to screen for ADC variants that are better trafficked into compartments of the desired $\mathrm{pH}$ for payload delivery ${ }^{53,54}$.

\section{ASSOCIATED CONTENT}

Supporting Information. Additional figures are available as a PDF.

\section{AUTHOR INFORMATION}

\section{Corresponding Author}

*Email; paszek@cornell.edu 
bioRxiv preprint doi: https://doi.org/10.1101/800003; this version posted October 10, 2019. The copyright holder for this preprint (which was not certified by peer review) is the author/funder, who has granted bioRxiv a license to display the preprint in perpetuity. It is made available under aCC-BY-NC-ND 4.0 International license.

\section{Author Contributions}

The manuscript was written through contributions of all authors. All authors have given approval to the final version of the manuscript. $₫$ These authors contributed equally.

\section{Notes}

The authors declare no competing financial interests.

\section{ACKNOWLEDGMENT}

This investigation was supported by National Institute of Health New Innovator DP2 GM229133 (M.J.P.), National Cancer Institute U54 CA210184-01 (M.J.P. and W.R.Z.), National Institute of General Medical Sciences Ruth L. Kirschstein National Research Service Award 2T32GM008267 (M.J.C.), and National Science Foundation Graduate Research Fellowship DGE-1650441 (M.J.C.). Imaging data was acquired through the Cornell University Biotechnology Resource Center, with NYSTEM C029155 and NIH S100D018516 funding for the shared Zeiss LSM880 microscope.

\section{REFERENCES}

(1) Corbet, C.; Feron, O. Tumour Acidosis: From the Passenger to the Driver's Seat. Nat. Rev. Cancer 2017, 17 (10), 577593. https://doi.org/10.1038/nrc.2017.77.

(2) Webb, B. A.; Chimenti, M.; Jacobson, M. P.; Barber, D. L. Dysregulated PH: A Perfect Storm for Cancer Progression. Nat. Rev. Cancer 2011, 11 (9), 671-677. https://doi.org/10.1038/nrc3110.

(3) Pavlova, N. N.; Thompson, C. B. The Emerging Hallmarks of Cancer Metabolism. Cell Metab. 2016, 23 (1), 27-47. https://doi.org/10.1016/j.cmet.2015.12.006.

(4) Szpiech, Z. A.; Strauli, N. B.; White, K. A.; Ruiz, D. G.; Jacobson, M. P.; Barber, D. L.; Hernandez, R. D. Prominent Features of the Amino Acid Mutation Landscape in Cancer. PLOS ONE 2017, 12 (8), e0183273. https://doi.org/10.1371/journal.pone.0183273.

(5) Damaghi, M.; Gillies, R. Phenotypic Changes of AcidAdapted Cancer Cells Push Them toward Aggressiveness in Their Evolution in the Tumor Microenvironment. Cell Cycle 2017, 16 (19), 1739-1743. https://doi.org/10.1080/15384101.2016.1231284.

(6) Hundshammer, C.; Düwel, S.; Schilling, F. Imaging of Extracellular PH Using Hyperpolarized Molecules. Isr. J. Chem. 2017, $\quad 57$ (9), 788-799. https://doi.org/10.1002/ijch.201700017.

(7) Hao, G.; Xu, Z. P.; Li, L. Manipulating Extracellular Tumour PH: An Effective Target for Cancer Therapy. RSC Adv. 2018, 8 (39), 22182-22192. https://doi.org/10.1039/C8RA02095G.

(8) Anderson, M.; Moshnikova, A.; Engelman, D. M.; Reshetnyak, Y. K.; Andreev, O. A. Probe for the Measurement of Cell Surface PH in Vivo and Ex Vivo. Proc. Natl. Acad. Sci. U. S. $\quad$ A. 2016, 113 (29), 8177-8181. https://doi.org/10.1073/pnas.1608247113.

(9) Chiche, J.; Brahimi-Horn, M. C.; Pouysségur, J. Tumour Hypoxia Induces a Metabolic Shift Causing Acidosis: A Common Feature in Cancer. J. Cell. Mol. Med. 2010, 14 (4), 771794. https://doi.org/10.1111/j.1582-4934.2009.00994.x.

(10) Parks, S. K.; Chiche, J.; Pouysségur, J. Disrupting Proton Dynamics and Energy Metabolism for Cancer Therapy. Nat. Rev. Cancer 2013, 13 (9), 611-623. https://doi.org/10.1038/nrc3579.

(11) Schnitzer, J. E. Glycocalyx Electrostatic Potential Profile Analysis: Ion, PH, Steric, and Charge Effects. Yale J. Biol. Med. 1988, 61 (5), 427-446.
Pearce, O. M. T.; Läubli, H. Sialic Acids in Cancer Biology and Immunity. Glycobiology 2016, 26 (2), 111-128. https://doi.org/10.1093/glycob/cwv097.

(13) Yang, Y.; Xia, M.; Zhao, H.; Zhang, S.; Zhang, X. A Cell-Surface-Specific Ratiometric Fluorescent Probe for Extracellular PH Sensing with Solid-State Fluorophore. ACS Sens. 2018, $\quad 3$ (11), 2278-2285. https://doi.org/10.1021/acssensors.8b00514.

(14) Weiner, G. J. Building Better Monoclonal Antibody-Based Therapeutics. Nat. Rev. Cancer 2015, 15 (6), 361-370. https://doi.org/10.1038/nrc3930.

(15) Wong, S.-F. Cetuximab: An Epidermal Growth Factor Receptor Monoclonal Antibody for the Treatment of Colorectal Cancer. Clin. Ther. 2005, 27 (6), 684-694. https://doi.org/10.1016/j.clinthera.2005.06.003.

(16) Traenkle, B.; Rothbauer, U. Under the Microscope: SingleDomain Antibodies for Live-Cell Imaging and Super-Resolution Microscopy. Front. Immunol. 2017, 8, 1030. https://doi.org/10.3389/fimmu.2017.01030.

(17) Muyldermans, S. Nanobodies: Natural Single-Domain Antibodies. Annu. Rev. Biochem. 2013, 82, 775-797. https://doi.org/10.1146/annurev-biochem-063011092449.

(18) Pleiner, T.; Bates, M.; Görlich, D. A Toolbox of Anti-Mouse and Anti-Rabbit IgG Secondary Nanobodies. J Cell Biol 2017, jcb.201709115. https://doi.org/10.1083/jcb.201709115.

(19) Virant, D.; Traenkle, B.; Maier, J.; Kaiser, P. D.; Bodenhöfer, M.; Schmees, C.; Vojnovic, I.; Pisak-Lukáts, B.; Endesfelder, U.; Rothbauer, U. A Peptide Tag-Specific Nanobody Enables High-Quality Labeling for DSTORM Imaging. Nat. Commun. 2018, 90 (1), 930. https://doi.org/10.1038/s41467-018-03191-2.

(20) Pleiner, T.; Bates, M.; Trakhanov, S.; Lee, C.-T.; Schliep, J. E.; Chug, H.; Böhning, M.; Stark, H.; Urlaub, H.; Görlich, D. Nanobodies: Site-Specific Labeling for Super-Resolution Imaging, Rapid Epitope-Mapping and Native Protein Complex Isolation. elife 2015, 4, e11349. https://doi.org/10.7554/eLife.11349.

(21) Rothbauer, U.; Zolghadr, K.; Tillib, S.; Nowak, D.; Schermelleh, L.; Gahl, A.; Backmann, N.; Conrath, K.; Muyldermans, S.; Cardoso, M. C.; et al. Targeting and Tracing Antigens in Live Cells with Fluorescent Nanobodies. Nat. Methods 2006, 3 (11), 887-889. https://doi.org/10.1038/nmeth953.

(22) Miesenböck, G.; Angelis, D. A. D.; Rothman, J. E. Visualizing Secretion and Synaptic Transmission with PH-Sensitive Green Fluorescent Proteins. Nature 1998, 394 (6689), 192-195. https://doi.org/10.1038/28190.

(23) Tsien, R. Y. The Green Fluorescent Protein. Annu. Rev. Biochem. 1998, 67 (1), 509-544. https://doi.org/10.1146/annurev.biochem.67.1.509.

(24) Sankaranarayanan, S.; De Angelis, D.; Rothman, J. E.; Ryan, T. A. The Use of PHluorins for Optical Measurements of Presynaptic Activity. Biophys. J. 2000, 79 (4), 2199-2208. Rodriguez, E. A.; Campbell, R. E.; Lin, J. Y.; Lin, M. Z.; Miyawaki, A.; Palmer, A. E.; Shu, X.; Zhang, J.; Tsien, R. Y. The Growing and Glowing Toolbox of Fluorescent and Photoactive Proteins. Trends Biochem. Sci. 2017, 42 (2), 111129. https://doi.org/10.1016/j.tibs.2016.09.010.

(26) Mahon, M. J. PHluorin2: An Enhanced, Ratiometric, PHSensitive Green Florescent Protein. Adv. Biosci. Biotechnol. $\begin{array}{llll}\text { Print 2011, } 2 & \text { (3), 132-137. }\end{array}$ https://doi.org/10.4236/abb.2011.23021.

(27) Shurer, C. R.; Colville, M. J.; Gupta, V. K.; Head, S. E.; Kai, F.; Lakins, J. N.; Paszek, M. J. Genetically Encoded Toolbox for Glycocalyx Engineering: Tunable Control of Cell Adhesion, Survival, and Cancer Cell Behaviors. ACS Biomater. Sci. 
bioRxiv preprint doi: https://doi.org/10.1101/800003; this version posted October 10, 2019. The copyright holder for this preprint (which was not certified by peer review) is the author/funder, who has granted bioRxiv a license to display the preprint in perpetuity. It is made available under aCC-BY-NC-ND 4.0 International license.

Eng. 2017. https://doi.org/10.1021/acsbiomaterials.7b00037.

(28) Frey, S.; Görlich, D. A New Set of Highly Efficient, TagCleaving Proteases for Purifying Recombinant Proteins. J. Chromatogr. A 2014, 1337, 95-105. https://doi.org/10.1016/j.chroma.2014.02.029.

(29) Magde, D.; Wong, R.; Seybold, P. G. Fluorescence Quantum Yields and Their Relation to Lifetimes of Rhodamine 6G and Fluorescein in Nine Solvents: Improved Absolute Standards for Quantum Yields. Photochem. Photobiol. 2002, 75 (4), 327-334. https://doi.org/10.1562/00318655(2002)0750327FQYATR2.0.CO2.

(30) Laviv, T.; Kim, B. B.; Chu, J.; Lam, A. J.; Lin, M. Z.; Yasuda, R. Simultaneous Dual-Color Fluorescence Lifetime Imaging with Novel Red-Shifted Fluorescent Proteins. Nat. Methods 2016, 13 (12), 989-992. https://doi.org/10.1038/nmeth.4046.

(31) Ward, W. W. Biochemical and Physical Properties of Green Fluorescent Protein. In Green Fluorescent Protein; John Wiley \& Sons, Ltd, 2005; pp 39-65. https://doi.org/10.1002/0471739499.ch3.

(32) Carmody, W. R. Easily Prepared Wide Range Buffer Series. J. Chem. Educ. 1961, 38 (11), 559. https://doi.org/10.1021/ed038p559.

(33) Cal, P. M. S. D.; Bernardes, G. J. L.; Gois, P. M. P. CysteineSelective Reactions for Antibody Conjugation. Angew. Chem. Int. Ed. 2014, 53 (40), 10585-10587. https://doi.org/10.1002/anie.201405702.

(34) Suzuki, T.; Arai, S.; Takeuchi, M.; Sakurai, C.; Ebana, H.; Higashi, T.; Hashimoto, H.; Hatsuzawa, K.; Wada, I. Development of Cysteine-Free Fluorescent Proteins for the Oxidative Environment. PLoS ONE 2012, 7 (5). https://doi.org/10.1371/journal.pone.0037551.

(35) Kufe, D. W. Mucins in Cancer: Function, Prognosis and Therapy. Nat. Rev. Cancer 2009, 9 (12), 874-885. https://doi.org/10.1038/nrc2761.

(36) Paszek, M. J.; DuFort, C. C.; Rossier, O.; Bainer, R.; Mouw, J. K.; Godula, K.; Hudak, J. E.; Lakins, J. N.; Wijekoon, A. C.; Cassereau, L.; et al. The Cancer Glycocalyx Mechanically Primes Integrin-Mediated Growth and Survival. Nature 2014, 511 (7509), 319-325. https://doi.org/10.1038/nature 13535 .

(37) Arteaga, C. L.; Engelman, J. A. ERBB Receptors: From Oncogene Discovery to Basic Science to Mechanism-Based Cancer Therapeutics. Cancer Cell 2014, 25 (3), 282-303. https://doi.org/10.1016/j.ccr.2014.02.025.

(38) Huotari, J.; Helenius, A. Endosome Maturation. EMBO J. 2011, 30 (17), 3481-3500. https://doi.org/10.1038/emboj.2011.286.

(39) Frampton, J. E. Cetuximab: A Review of Its Use in Squamous Cell Carcinoma of the Head and Neck. Drugs 2010, 70 (15), 1987-2010. https://doi.org/10.2165/11205010000000000-00000.

(40) Galizia, G.; Lieto, E.; De Vita, F.; Orditura, M.; Castellano, P.; Troiani, T.; Imperatore, V.; Ciardiello, F. Cetuximab, a Chimeric Human Mouse Anti-Epidermal Growth Factor Receptor Monoclonal Antibody, in the Treatment of Human Colorectal Cancer. Oncogene 2007, 26 (25), 3654-3660. https://doi.org/10.1038/sj.onc.1210381.

(41) Liao, H.-J.; Carpenter, G. Cetuximab/C225-Induced Intracellular Trafficking of Epidermal Growth Factor Receptor. Cancer Res. 2009, 69 (15), 6179-6183. https://doi.org/10.1158/0008-5472.CAN-09-0049.

(42) Merlino, G. T.; Xu, Y. H.; Ishii, S.; Clark, A. J.; Semba, K.; Toyoshima, K.; Yamamoto, T.; Pastan, I. Amplification and
Enhanced Expression of the Epidermal Growth Factor Receptor Gene in A431 Human Carcinoma Cells. Science 1984, 224 (4647), 417-419. https://doi.org/10.1126/science.6200934.

(43) Theofilopoulos, A. N.; Dixon, F. J. The Biology and Detection of Immune Complexes. Adv. Immunol. 1979, 28, 89220.

(44) Almagro, J. C.; Daniels-Wells, T. R.; Perez-Tapia, S. M.; Penichet, M. L. Progress and Challenges in the Design and Clinical Development of Antibodies for Cancer Therapy. Front. Immunol. 2017, $\quad 8, \quad 1751$. https://doi.org/10.3389/fimmu.2017.01751.

(45) Chames, P.; Van Regenmortel, M.; Weiss, E.; Baty, D. Therapeutic Antibodies: Successes, Limitations and Hopes for the Future. Br. J. Pharmacol. 2009, 157 (2), 220-233. https://doi.org/10.1111/j.1476-5381.2009.00190.x.

(46) Tintelnot, J.; Baum, N.; Schultheiß, C.; Braig, F.; Trentmann, M.; Finter, J.; Fumey, W.; Bannas, P.; Fehse, B.; Riecken, K.; et al. Nanobody Targeting of Epidermal Growth Factor Receptor (EGFR) Ectodomain Variants Overcomes Resistance to Therapeutic EGFR Antibodies. Mol. Cancer Ther. 2019, 18 (4), 823-833. https://doi.org/10.1158/1535-7163.MCT-18-0849.

(47) Nath, S.; Mukherjee, P. MUC1: A Multifaceted Oncoprotein with a Key Role in Cancer Progression. Trends Mol. Med. 2014, $20 \quad$ (6), 332-342. https://doi.org/10.1016/j.molmed.2014.02.007.

(48) Dan, N.; Setua, S.; Kashyap, V. K.; Khan, S.; Jaggi, M.; Yallapu, M. M.; Chauhan, S. C. Antibody-Drug Conjugates for Cancer Therapy: Chemistry to Clinical Implications. Pharm. Basel Switz. 2018, 11 https://doi.org/10.3390/ph11020032.

(49) Glatt, D. M.; Beckford Vera, D. R.; Prabhu, S. S.; Mumper, R. J.; Luft, J. C.; Benhabbour, S. R.; Parrott, M. C. Synthesis and Characterization of Cetuximab-Docetaxel and Panitumumab-Docetaxel Antibody-Drug Conjugates for EGFR-Overexpressing Cancer Therapy. Mol. Pharm. 2018, 15 (11), 5089-5102. https://doi.org/10.1021/acs.molpharmaceut.8b00672.

(50) Woehler, A. Simultaneous Quantitative Live Cell Imaging of Multiple FRET-Based Biosensors. PLoS ONE 2013, 8 (4). https://doi.org/10.1371/journal.pone.0061096.

(51) Condon, K. H.; Ehlers, M. D. CHAPTER 8 - Postsynaptic Machinery for Receptor Trafficking. In Protein Trafficking in Neurons; Bean, A. J., Ed.; Academic Press: Burlington, 2007; pp 143-174. https://doi.org/10.1016/B978012369437-9/50013-X.

(52) Kang, J. C.; Sun, W.; Khare, P.; Karimi, M.; Wang, X.; Shen, Y.; Ober, R. J.; Ward, E. S. Engineering a HER2-Specific Antibody-Drug Conjugate to Increase Lysosomal Delivery and Therapeutic Efficacy. Nat. Biotechnol. 2019, 37 (5), 523-526. https://doi.org/10.1038/s41587-019-0073-7.

(53) Kalim, M.; Chen, J.; Wang, S.; Lin, C.; Ullah, S.; Liang, K.; Ding, Q.; Chen, S.; Zhan, J. Intracellular Trafficking of New Anticancer Therapeutics: Antibody-Drug Conjugates. Drug Des. Devel. Ther. 2017, 11, 2265-2276. https://doi.org/10.2147/DDDT.S135571.

(54) Tsui, C. K.; Barfield, R. M.; Fischer, C. R.; Morgens, D. W.; Li, A.; Smith, B. A. H.; Gray, M. A.; Bertozzi, C. R.; Rabuka, D.; Bassik, M. C. CRISPR-Cas9 Screens Identify Regulators of Antibody-Drug Conjugate Toxicity. Nat. Chem. Biol. 2019, 15 (10), 949-958. https://doi.org/10.1038/s41589-0190342-2. 
bioRxiv preprint doi: https://doi.org/10.1101/800003; this version posted October 10, 2019. The copyright holder for this preprint (which was not certified by peer review) is the author/funder, who has granted bioRxiv a license to display the preprint in perpetuity. It is made available under

A

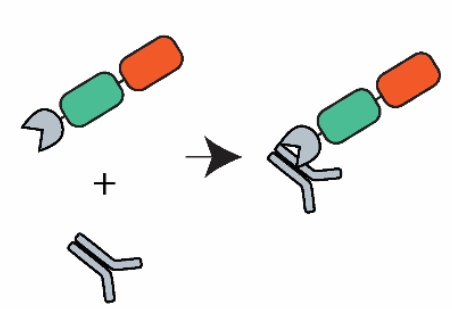

B

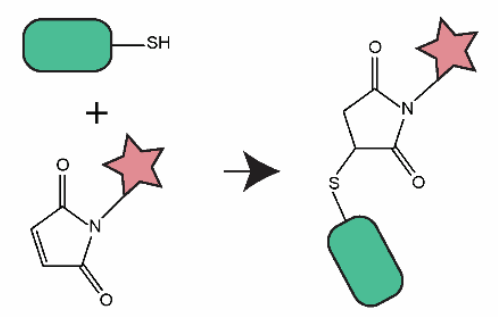

C CfSEP-ATTO490LS
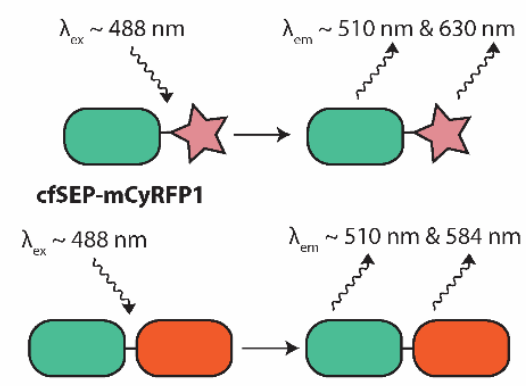

D
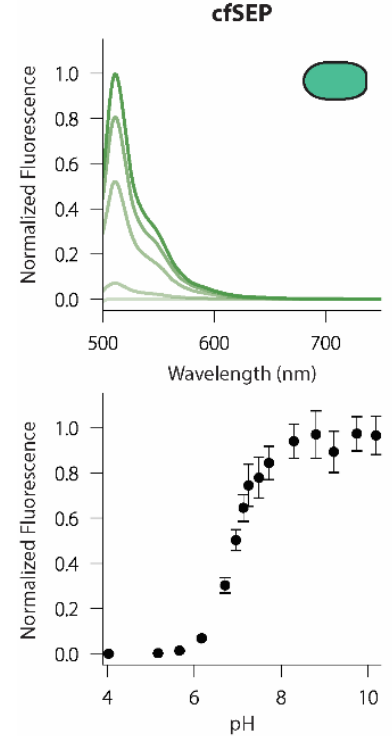
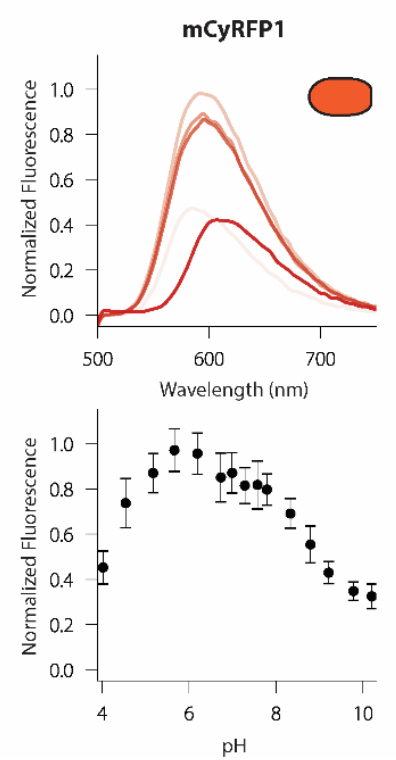

TP1107-CfSEP-ATTO490LS
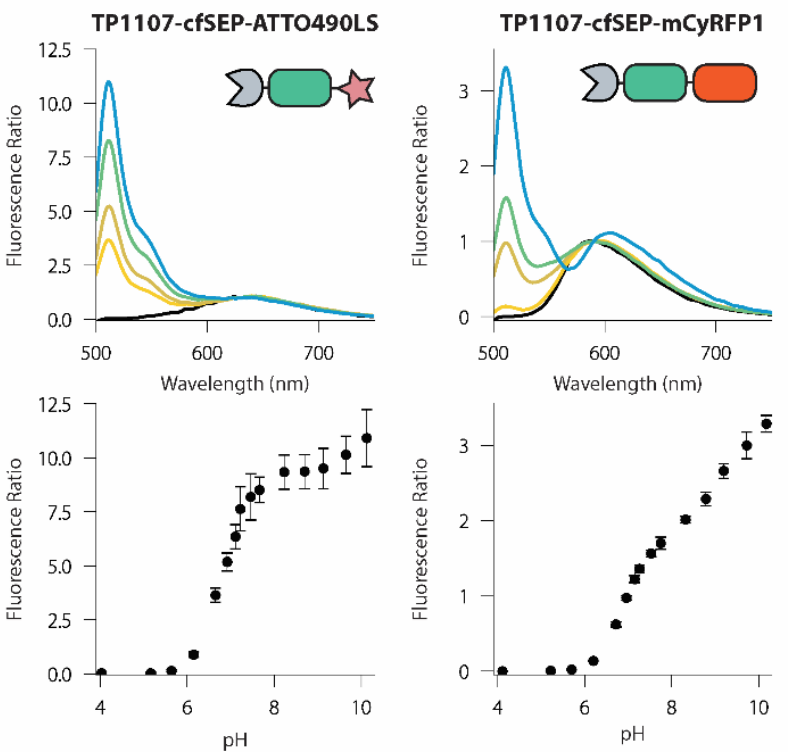

Figure 1. Litmus-body design and solution properties. A) Overview of the Litmus-body. A pH-sensitive GFP derivative (green) and red fluorophore (red) are fused to an anti-IgG nanobody (grey), allowing for targeting of primary antibodies. B) Reaction scheme for the conjugation of cfSEP to a maleimide-bound fluorophore. C) Scheme of the dual emission nature of the Litmus-body, using both ATT0490LS (top) and mCyRFP1 (bottom) as the long Stokes-shift red fluorescence emitter for ratiometric normalization of green sensor emission. red fluorophore. D) Fluorescence spectra and pH responsiveness of TP1107-cfSEP-mCyRFP1, TP1107-cfSEPATT0490LS, and their constituent fluorescent proteins. The fluorescence ratio for TP1107-cfSEP-mCyRFP1 was calculated as (I510/I590), while the fluorescence ratio for TP1107-cfSEP-ATT0490LS was calculated as (I510/I630). Error bars represent standard deviation of three independent experiments, each with triplicate. 
bioRxiv preprint doi: https://doi.org/10.1101/800003; this version posted October 10,2019 . The copyright holder for this preprint (which was not certified by peer review) is the author/funder, who has granted bioRxiv a license to display the preprint in perpetuity. It is made available under

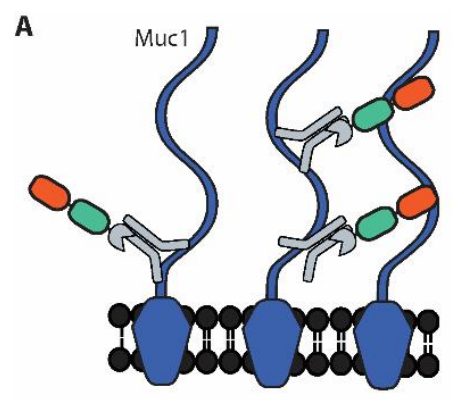

C
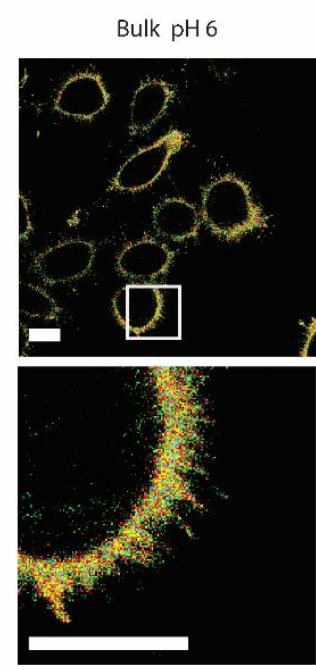

E

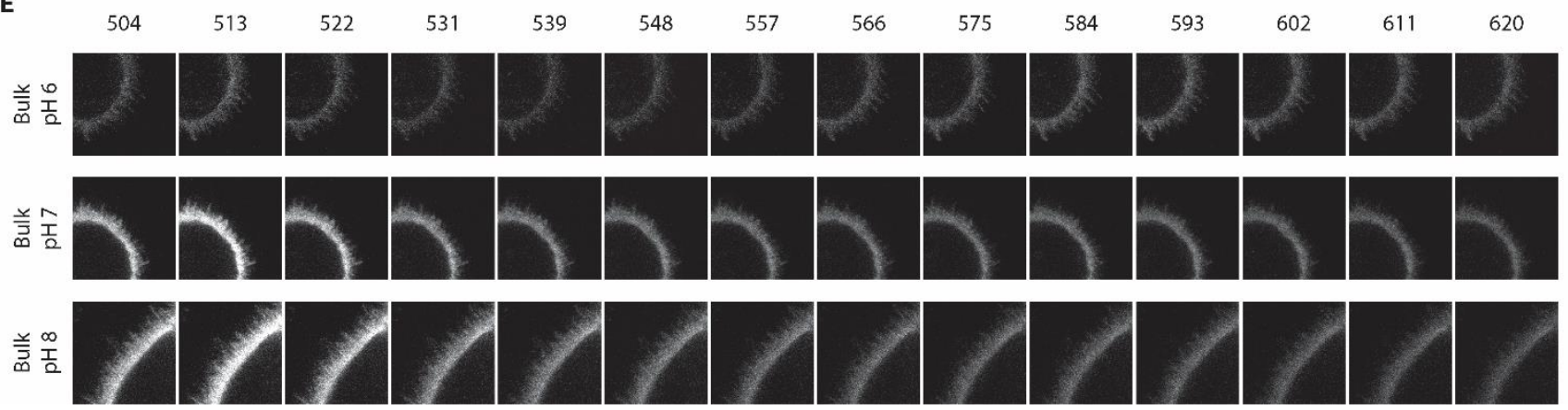

B

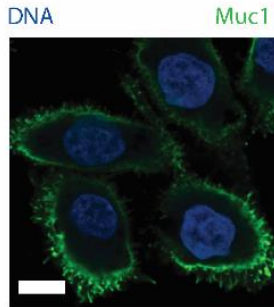

Positive Control

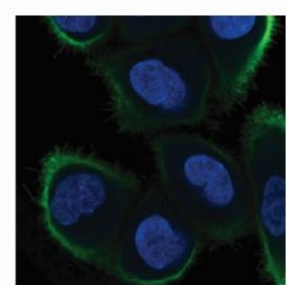

Primary + Litmus-body

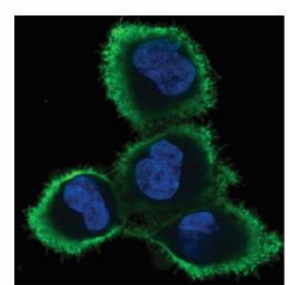

Precoupled

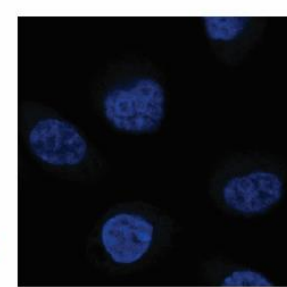

Negative Control
D
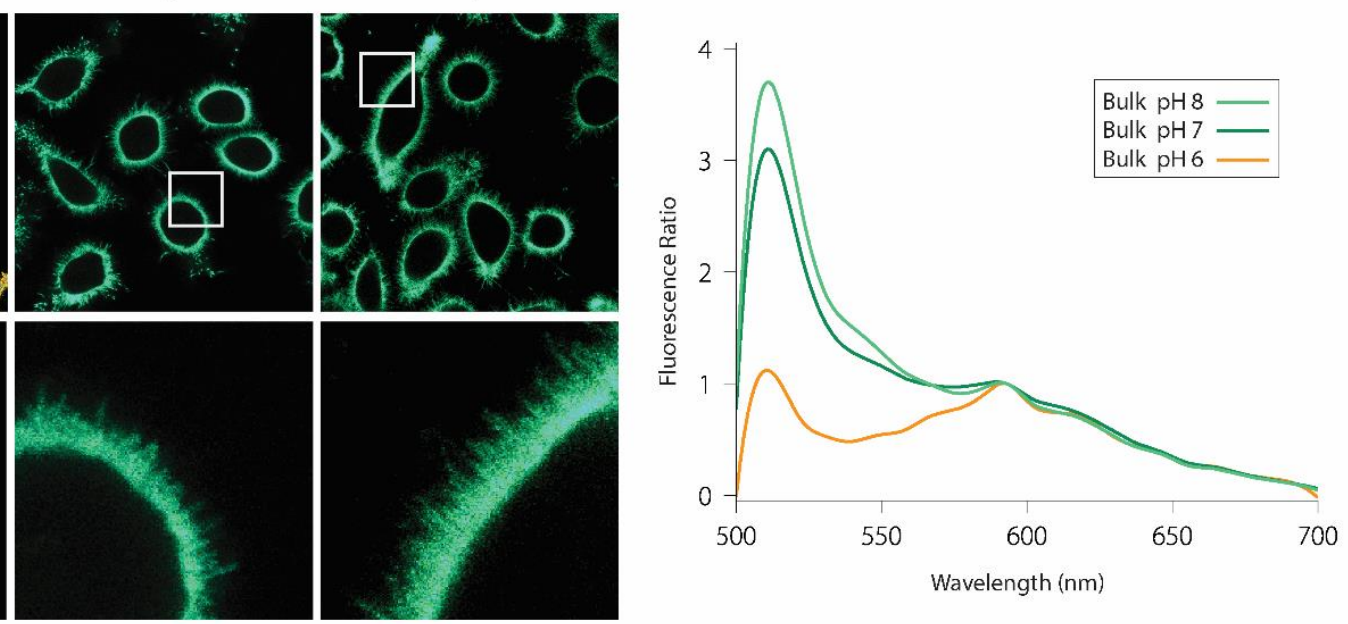

Wavelength $(\mathrm{nm})$

\section{0}


bioRxiv preprint doi: https://doi.org/10.1101/800003; this version posted October 10, 2019. The copyright holder for this preprint (which was not certified by peer review) is the author/funder, who has granted bioRxiv a license to display the preprint in perpetuity. It is made available under

A

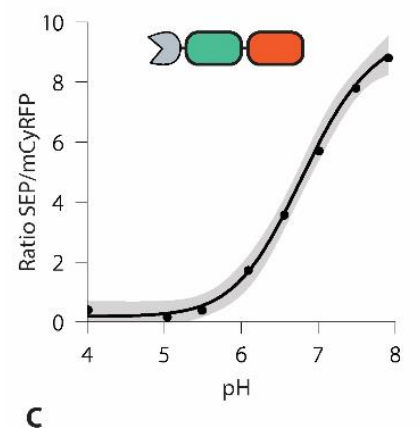

C
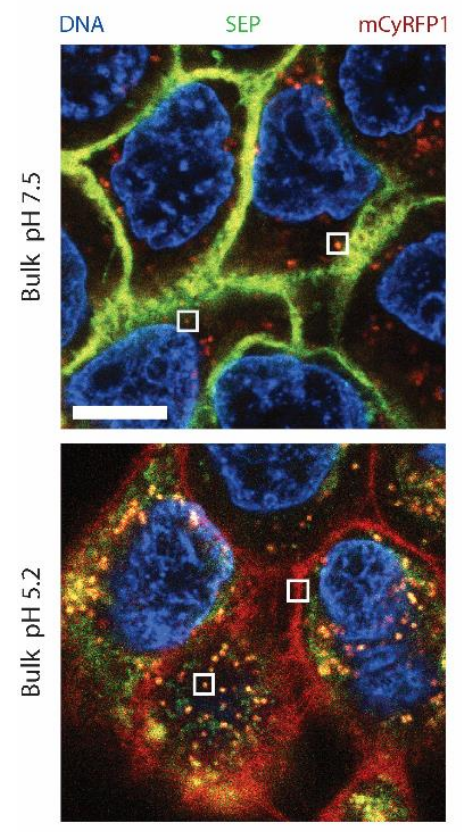

Composite

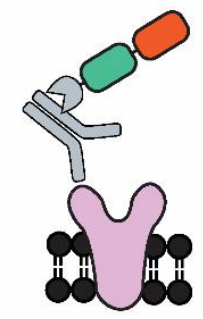

Plasma membrane

D pH scale bar

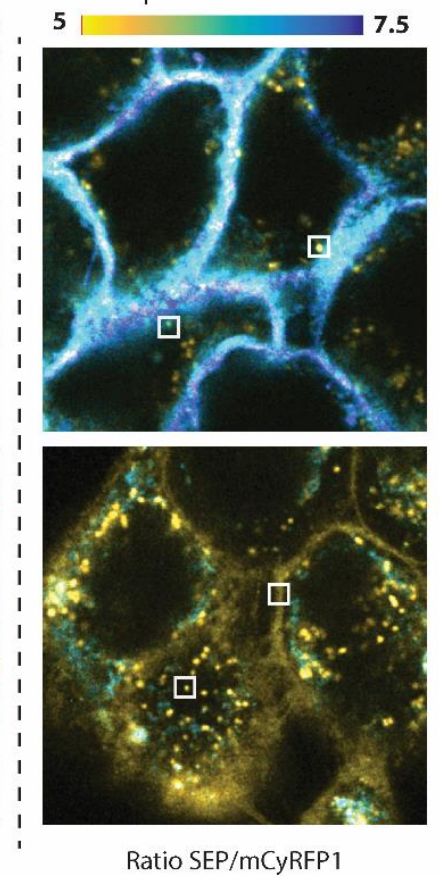

Recycling Endosome

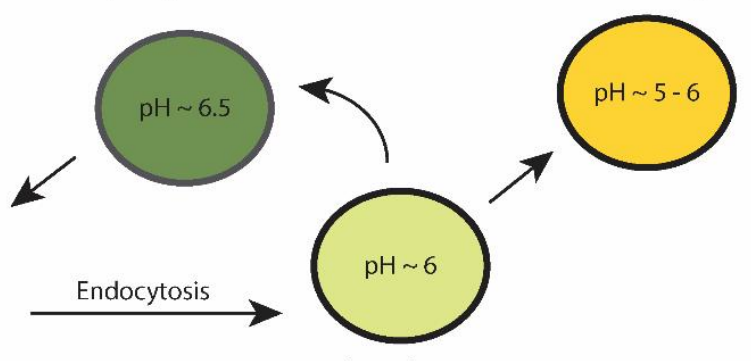

Early Endosome

$\mathbf{E}$
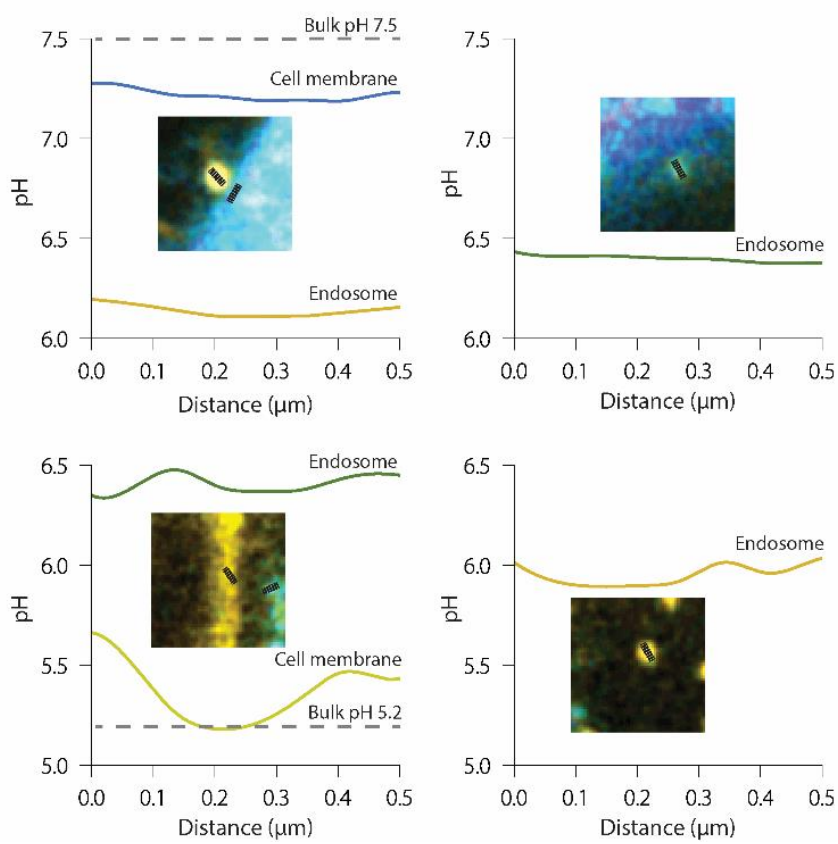

Figure 3. Litmus-bodies readily detect $\mathrm{pH}$ changes along the endocytic pathway. A) In-solution calibration of the Litmus-body based on (ISEP/I $\mathrm{I}_{\mathrm{mCyRF} 1}$ ) at various bulk $\mathrm{pH}$. Points were fitted to a four parameter logistic function. Grey-shaded regions represented a $95 \%$ CI. B) Scheme depicting the nature of binding between epidermal growth factor receptor (EGFR), and pre-coupled anti-EGFRLitmus-Body on EGFR overexpressing A431s. Upon binding to EGFR, the IgG-Litmus-body complex is endocytosed, allowing it to monitor changes in $\mathrm{pH}$ along the pathway. C) Representative live cell fluorescence images of pre-coupled anti-EGFR and Litmusbody binding to EGFR overexpressing A431s and being endocytosed. Top: bulk solution pH of 7.5. Bottom: Bulk solution of 5.2. D)

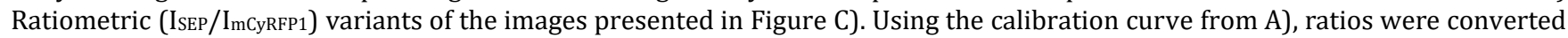
to $\mathrm{pH}$ values. E) Line traces (black lines) were taken from regions of interest in C/D) (white boxes, inline in E)). Scale bar: $10 \mu \mathrm{m}$. 
bioRxiv preprint doi: https://doi.org/10.1101/800003; this version posted October 10, 2019. The copyright holder for this preprint (which was not certified by peer review) is the author/funder, who has granted bioRxiv a license to display the preprint in perpetuity. It is made available under aCC-BY-NC-ND 4.0 International license.

Table 1. Photophysical properties and $\mathrm{pH}$ response characteristics of fluorescent proteins and constructs.

\begin{tabular}{|l|l|l|l|l|l|}
\hline Construct & $\begin{array}{l}\text { Emission Maxima } \\
(\mathrm{nm})\end{array}$ & $\begin{array}{l}\text { Quantum } \\
\text { Yield }\end{array}$ & $\begin{array}{l}\text { Extinction Coefficient } \\
\left(\mathrm{mM}^{-1} \mathrm{~cm}^{-1}\right)\end{array}$ & $\begin{array}{l}\text { Brightness } \\
\left(\mathrm{mM}^{-1} \mathrm{~cm}^{-1}\right)\end{array}$ & $\begin{array}{l}\text { Fold } \\
\left(\mathrm{pH} 7.5 / \mathrm{pH}^{5} .5\right)\end{array}$ \\
\hline SEP & 512 & 0.53 & 31 & 16.50 & 162 \\
\hline cfSEP & 510 & 0.48 & 29 & 13.99 & 80 \\
\hline mCyRFP1 & 583 & 0.31 & 27 & 8.34 & 0.87 \\
\hline TP1107-cfSEP-mCyRFP1 & $510 ; 583$ & 0.37 & 29 & 10.54 & 106 \\
\hline
\end{tabular}

